\title{
Corporate Social Responsibility as a tool to ensure sustainability and competitiveness of the monotowns
}

\author{
AsyaSechina $^{1, \mathrm{a}}$, Anna Fedenkova ${ }^{1}$, Natalia Pokrovskaya ${ }^{2}$ and Alena Kropova ${ }^{1}$ \\ ${ }^{1}$ Tomsk Polytechnic University, 634050 Lenin Avenue, 30, Tomsk, Russia \\ ${ }^{2}$ Saint-Petersburg State University, 199034 Universitetskaya nab., 7/9, St. Petersburg, Russia.
}

\begin{abstract}
Learning the basics and trends of the development of corporate social responsibility is connected with the need to identify the reasons for its humanization and globalization in today's business environment. Sustainability and competitiveness is one of the important characteristics of the company today. The characteristic of the Russian practice of corporate social responsibility highlights its features, levels and forms of development. Monotowns are a highly vulnerable category of Russian communities; they are in constant risk due to their specific characteristics and largely the underdeveloped economic base. The problems of monoprofile towns usually do not have simple solutions. They require a comprehensive approach and taking account of the existence and development of each monotown. The article deals with the concept of a monoprofile town, stages of formation and evolution of this phenomenon in the Russian economy. There is the problem of application of corporate social responsibility in the practice of Russian monotowns. There is the characteristic advantage of social responsibility in the monotowns. There is the influence of the organizations activities operating in a monotown on the quality of life of the population. There is the necessity of the use of corporate social responsibility in monotowns to enhance their sustainability and improve competitiveness.
\end{abstract}

\section{Introduction}

Corporate social responsibility (CSR) is a concept according to which the organization is responsible not only for its direct activities, but also for the interests of society. In the understanding of this approach, the organization is obliged to take into account the interests of consumers, suppliers, customers, investors, local communities and many other stakeholders in its activities. In modern science, there is a classical model of CSR, based on the fact that the economic interests of the organization or the business focus not only on profit, but also on improving its own external environment or "habitat" by the so-called "social investment" in certain social and economic spheres. The condition for the effectiveness of the classical model of CSR is an open society, where the model is used. For example, to address some social problems requires the presence of real labor market opportunities open to the redistribution of the labor market. In this situation, the employees given a choice will prefer a socially responsible employer. The employer is interested in qualified and loyal employees and will do everything possible in this direction for the attractiveness of his or her business.
Back in the late 90s of the XX century, scientists have concluded that the companies involved in CSR demonstrated better financial performance, in contrast to their competitors not involved in such practices. From the results of the study at Harvard University it can be concluded that companies that take into account the interests of their stakeholders grow 4 times faster than those of their competitors. Also employment in these companies is 8 times higher than that of the companies which take into account only the interests of their shareholders. Foreign experience shows that CSR is perceived as one of the strategic directions of development of the company. In particular, this is reflected in the selection of stakeholders with whom relations are priority for the company. It is expressed first of all in the choice of specific stakeholders whose interests will be determined by the company.

The principle of corporate social responsibility is that the rational economic interests oriented to business are not only maximizing profit but also reflecting the interests of its environment: social, environmental and political. This scheme shows the main stakeholders of the organization. The interests of investors, shareholders and suppliers are related to the efficiency of organization management (profitable using of resources). Employees expect adequate remuneration,

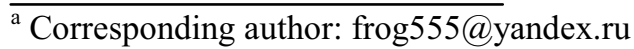


opportunities for professional growth and making themselves a business career, a healthy moral atmosphere, and acceptable conditions of work, good leadership. Consumers are interested in the quality, safety and accessibility of goods and services. Local governments are interested in the replenishment of the budget through tax revenue and jobs for the people living in the region. The interests of creditors are satisfied by the timely fulfillment of obligations on repayment of interest and loans. The state is interested in stability and sustainability of the economy, the significant role of business in a social and economic sphere both for a separate region and for the whole country. It is possible to mention that, the managers of the organization are most interested in the CSR programs. Corporate social responsibility is embedded in the company's strategy and its mission. The interest of managers is to increase productivity in the company, improving its image, the coverage of the activities of the company in the media (in direct advertising of goods and services), reducing staff turnover and attracting the best talent. Also the areas of the interest of managers include: stability and sustainability of the company in the future, the possibility of attracting foreign capital (companies practicing CSR are more attractive to foreign partners), as well as the possibility of obtaining tax benefits. The classical scheme of stakeholders is represented in Figure 1.

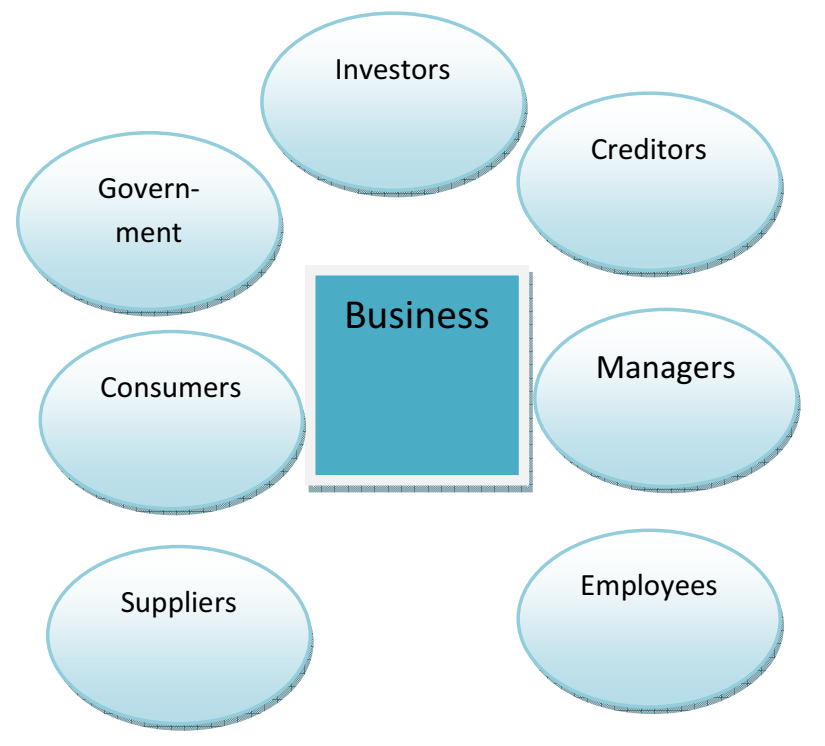

Fig. 1. Interaction between business and stakeholders

Companies carefully plan and record their actions in the field of CSR in their program documents. There is a practice of creating specialized committees at the Board of Directors among the Western companies. The company also introduces the post of Vice President of CSR, i.e. CSR activities are to be introduced at the top management level in Western companies.

If the company is striving to become a leader in its field, the management of socially responsible business will be a competitive advantage. In this case, the company must demonstrate the publicity of information for all parties interested in its operations, allowing strengthening the leadership position in the industry.

Also, information transparency and the use of the potential of CSR will work to improve the situation in the countries where the company operates.

Today it is evident that socially responsible business helps not only to attract potential investors, but also to retain them in the future

Advantages of CSR:

- growth of the shareholder's value of the company's capital

- $\quad$ access to public social investment

- the lower cost of capital

- risk reduction due to the interaction with stakeholders

There are three levels of corporate social responsibility. At the first level, the company only performs direct obligations to the society, such as:

- $\quad$ paying out wages to employees;

- compliance with labor legislation;

- timely payment of taxes

- adherence to safety standards in the production process

- $\quad$ providing the quality of products

The second level involves the interests of employees. In addition to the above-mentioned liabilities, it is assumed to have a set of benefits and services from the company such as:

- Social Investments - the program aimed at improving the life of the worker and her or his family;

- Investments in human capital - training and development of the staff, improving employees' workplaces, health promotion and labor organization for employees.

The third level is external to the company, which is beyond the scope of the company, unlike the previous one. The tool for third level is the population of the territory where the organization or certain categories of this population operate. For example, this can be a program, the purpose of which is to initially improve the company's business, which would later produce a social effect. For example, there is the development of the transport infrastructure settlement, the expansion of streets, etc. Unlike traditional forms associated with tax payments, this form allows us to track the effects of such activities and to get the result in the form of improved living standards.

One of the terms of reference of such activities is to improve and expand partnerships with the local administration and other Governmental Bodies. Therefore, social responsibility in the broadest sense involves the participation of the authorities in carrying out social policy aimed at the development of society.

Now CSR in Russia is in its infancy. Although some forms of business ethics and CSR were present in the Russian business before the revolution. Perhaps due to the fact that the historical events, which originated the principles, were lost and now there is an opinion that the conduct of socially responsible business is contrary to the main aim of the organization, namely making a profit. 
For the Russian business, this approach is relatively new and its embodiment 'hinders' a number of existing problems and stereotypes. For example, there is an opinion that if the organization complies with legislation, on time and in full, pays taxes, has employees, it is the embodiment of social responsibility of business. Also one of the CSR implementation problems at Russian enterprises is the instability of the environment, not allowing organizations to do their own study of strategic development and, as a consequence, learning opportunities to plan work on the social responsibility of business. Often the approach to social investment is unsystematic; CSR refers to sponsorship and patronage. Donations are collected selectively, without having clear waste regulations, spending is not transparent. Also the peculiarities of the Russian CSR can be attributed to extreme politicization of this issue. The practice of CSR application in Russia should be based on the features that our society is not so open that it was in a classical model of CSR.

Thus we can draw the following conclusions:

- funds allocated for CSR are spent inefficiently

- the old social system is not evolving, but rather conserved

- business does not know the real needs of society

\section{Results and discussion}

Identified problems are even more acute when it comes to monoprofile towns. The town-forming enterprise in the city performs the following functions:

- $\quad$ providing jobs;

- $\quad$ providing the tax base;

- $\quad$ providing the socially oriented activities.

The relevance of socially responsible business in such cities is obvious, as all activities of the townforming enterprise directly affects the comfort of the population living in monotowns.

Comfortable accommodation is regarded as a set of social, physical, psychological factors and people's perceptions in terms of cultural features and values prevailing in a particular society.

The main criteria for monoprofile towns include the presence in the city of one or several large enterprises, which employ at least a quarter of the total population, the dependence of the city budget from the activity of the enterprise, low diversification of the scope of employment of the working population, low mobility due to the remoteness from major cities, low infrastructure development of the city. At this point, inhabitants of monoprofile towns suffer from high unemployment. The city authorities do not have the possibility of financial investments in the infrastructure of the city. It is clear that in the case of closing unprofitable enterprises unemployed will be the majority of inhabitants of monotowns.

At present, in Russia, there are about 470 monotowns with a population of several thousand people. According to studies of monoprofile towns, today there are 40 percent of Russian cities of such type. The two basic problems of monotowns are:

- $\quad$ as a result of the transition from a planned economy (namely the Soviet planned economy created monotowns) to a market economy, the products of these companies become exposed to certain risks;

- $\quad$ low mobility of the population $(70 \%$ of the population are not ready to leave their permanent residence), which should be understood as low mobility of change.

All monoprofile towns have problems of varying difficulty and require different levels of interference including that from the state. For example, the monitoring of the condition of towns and settlements, characterized by a stable situation, because the crisis in a special way has not affected them, allows assistance in the modernizing of production, taking into account the participation of state-owned banks, the reorientation of production that is unprofitable from the point of view of economy, as well as the establishment of the Federal targeted programs and the resettlement of some settlements. The problems characterizing the monotowns usually do not have simple and standard solutions. It is necessary to take into account a variety of specializations, the features of the Genesis, regional characteristics, and the interests of the population of monotowns. One of the reasons for the negative social and economic situation is the insufficient level of interaction between the federal and local governments in the development of strategic plans.

The problem of monotowns did not emerge at once. The experience of the economic development in Russia already gives the opportunity to solve these problems. Decisions are possible if they will be based on the real needs of the population, based on careful monitoring of the interests of the population, business and city authorities.

Accordingly, we should define the essence of corporate social responsibility for monoprofile towns. This is a concept according to which the company takes into account the interests of the inhabitants of monoprofile towns, takes responsibility for the impact of its activities on shareholders and suppliers, as well as the entire population of the city. In addition, the company is responsible for the competitiveness of the entire city, while strengthening its own competitiveness.

\section{Conclusion}

Monotowns suffer from the effects of the reduction of development programs, the destruction of urban identity, reducing investment in education and health care. The problem is that there is the outflow of the intellectual potential, as qualified young people move to larger and more developed cities. There is a decrease of intellectual and social capital, beginning from the demographic component and ending with the level of education and health.

Features of the social situation in monotowns create a special approach to strategic planning and 
development approaches to the management of this kind of cities.

However, there are serious risks associated with making a management decision at the levels of topmanagement in monotowns. Any wrong decision in a given social environment may lead to the loss of essential human resources and further destruction of monotowns. However, there are some alternative options of corporate social responsibility that can change the situation and direct the management of the city development. In the creation of the CSR action plan, it is important to assess the risk of loss at the level of city management and alternative options for its implementation.

There is necessary preliminary step-by-step examination and evaluation of every decision to reduce the risk of managerial decision-making. It is also necessary to define the limit of financial resources for the implementation of this decision. Alternatively, it is necessary to consider diversification of defined risks that may be realized in the development and support of a full CSR plan that includes various activities.

In this regard, there are certain issues related to the potential participation of large companies in the process of town management, the willingness of local communities to influence the activities of authorities, monitoring issues related to the improvement of living conditions in a monoprofile town.

The work should be aimed at the formation and implementation of CSR programs. A comprehensive approach should include the following steps:

- monitoring the interests of the population of monotowns;

- $\quad$ analysis of the needs of employers

- elaboration of CSR programs (individually for each region)

- coordination of the activities in the field of CSR

First of all, the authorities in the region or specific monotowns should be interested in this issue and should work in close connection with the business. The city administration must be interested in improving the image of enterprises operating on its territory. These can be activities such as the organization of competitions in the field of corporate social responsibility, information support of activities carried out by the company in this area.

In addition, regional authorities may carry out subsidies for the implementation of activities aimed at the creation and development of corporate social responsibility in the region; funding for training and advanced training in the field of business ethics and CSR. In addition, it is necessary to conduct workshops to exchange experience in the social sphere as well as company management, to provide methodological support in matters related to ethical conflicts and to the sphere of relations "boss-subordinate".

The work directed at a socially responsible business should be conducted according to clear and transparent rules. However, as there is no practical recommendation in this area in the Russian business, it is necessary to carry out this work based on the specificity of each monotown.

The most important issue is the monitoring of the needs of population and employees. Therefore, the feedback tools are necessary at every level of relations (employee-employer, employer-authorities). This procedure may consist in monitoring the social environment of the organization and the analysis of the changes occurring in it. Also in the world and domestic practice, there are accepted standards of CSR (Social Accountability 8000, ISO 26000), providing certain procedures and indicators that aim to help employers to control the implementation process and work in the field of CSR.

In addition, the assessment of the social situation in monotowns is important. It refers to the following factors: the professional level, the presence of additional education, or the presence of improvement of qualification in the main occupation, the desire to climb the career ladder and to grow professionally, the possibility of changing the professional profile as well as motivational factors. It is clear that the purpose of such research will be the analysis of the employee mobility.

It is necessary to use a test and a questionnaire for such research. It is important that the goal of such research should be to analyze the opportunities of training and retraining, and to identify the needs of families who will be forced to move to another region.

After a phase of monitoring it is necessary to develop CSR program on this basis, which must be specific and appropriate to the specifics of each individual monotown.

Based on the international experience, we have concluded that socially responsible business should be a part of the development strategy of a monotown, and a region. Accordingly, an important factor is the connection with the problem of academic institutions of a given region, which have experience in strategic and social planning and, thus, could coordinate the actions of the authorities and their own businesses.

Thus it can be concluded that the implementation of CSR programs in the Russian monotowns may become an impetus for the restoration or re-production, and, consequently, the restoration of their life activity, which will have a beneficial impact on the economy and social sphere.

\section{References}

1. P.R.P. Coelho, J.E. McClure, J.A. Spry, AmericanJournal of Business, 18, 1 (2003)

2. S. von Thun, Friedemann (Rowohlt, 1981)

3. A.B. Carroll, Business Horizon, July-August, (1991)

4. C.W.Morris, Foundations of the Theory of Sign (1938)

5. M.Schwartz, Corporate Social Responsibility: An ethical approach (2011) 
6. N.V. Cherepanova, Proceedings of the International Conference on RPTSS-2014 (Tomsk, TPU, 2015)

7. N.O. Chistyakova, A.S. Fedenkova, N.V. Shabaldina, Y.V. Abushakhmanova, Proceedings of IBIMA (2015)

8. S. Jastram, CIS Papers, 17, (2007)

9. I.M. Okwo, D.O. Ugwunta, A.U. Nweze, European Journal of Business and Management, 4, $20(2012)$ 